Curr Opin Gastroenterol. 2017 September ; 33(5): 374-382. doi:10.1097/MOG.0000000000000386.

\title{
Obesity and pancreatitis
}

\author{
Biswajit Khatua, Bara El-Kurdi, and Vijay P. Singh \\ Department of Medicine, Mayo Clinic, Scottsdale, Arizona, USA
}

\begin{abstract}
Purpose of review-The obesity pandemic poses a unique set of problems for acute pancreatitis - both by increasing acute pancreatitis incidence, and worsening acute pancreatitis severity. This review explores these associations, underlying mechanisms, and potential therapies.

Recent findings-We review how the obesity associated increase in gallstones, surgical, and endoscopic interventions for obesity management, diabetes, and related medications such as incretin-based therapies and hypertriglyceridemia may increase the incidence of acute pancreatitis. The mechanism of how obesity may increase acute pancreatitis severity are discussed with a focus on cytokines, adipokines, damage-associated molecular patterns and unsaturated fatty acidmediated lipotoxicity. The role of obesity in exacerbating pancreatic necrosis is discussed; focusing on obesity-associated pancreatic steatosis. We also discuss how peripancreatic fat necrosis worsens organ failure independent of pancreatic necrosis. Last, we discuss emerging therapies including choice of intravenous fluids and the use of lipase inhibitors which have shown promise during severe acute pancreatitis.
\end{abstract}

Summary-We discuss how obesity may contribute to increasing acute pancreatitis incidence, the role of lipolytic unsaturated fatty acid release in worsening acute pancreatitis, and potential approaches, including appropriate fluid management and lipase inhibition in improving acute pancreatitis outcomes.

\section{Keywords}

lipase inhibition; obesity; pancreatitis; unsaturated fatty acids

\section{INTRODUCTION}

Obesity is a growing pandemic [1] with increasing healthcare costs, and acute pancreatitis is one of the most common gastroenterological causes for hospitalization in the United States affecting 275000 patients annually [2]. Obesity has likely contributed to increasing the incidence [2,3] and severity [4-11] of acute pancreatitis. Here we discuss the underlying mechanisms, and emerging acute pancreatitis management options based on clinically relevant studies.

Correspondence to Vijay P. Singh, MD, Division of Gastroenterology and Hepatology, Mayo Clinic, Scottsdale, AZ 85259, USA., Tel: +1 480301 4286; fax: +1 480301 7017; singh.vijay@ mayo.edu.

Conflicts of interest

There are no conflicts of interest. 


\section{DISCUSSION}

Obesity describes excessive adiposity, and currently afflicts humans in pandemic proportions. Visceral abdominal adiposity has the biggest impact on acute pancreatitis $\left[12,13^{\square}, 14\right]$. Although the definition of obesity varies, on a global scale more than $35 \%$ of adults are overweight $\left(\mathrm{BMI}>25 \mathrm{~kg} / \mathrm{m}^{2}\right)$ and more than $10 \%$ are obese $\left(\mathrm{BMI}>30 \mathrm{~kg} / \mathrm{m}^{2}\right)$ [15]. Interestingly, when defined by criteria accepted by national organizations, the proportion with obesity increases. For example, although only about $4 \%$ of men in China or Japan, and 34\% in the United States have a BMI of more than 30 [15]; based on waist circumference cutoffs relevant to these countries, more than $35 \%$ of adult men in all three countries are obese [16]. Therefore, despite the varying definitions of obesity, the rates of abdominal adiposity are similarly high across the globe. This is important as over the last 3 decades, both the prevalence of obesity [1] and incidence of pancreatitis $[3,17]$ have increased. Moreover, as we discuss below, obese patients have a higher risk of severe acute pancreatitis (SAP). In the following section, we will separately discuss the pathophysiology of how obesity may increase the incidence, and also worsen the severity of acute pancreatitis.

\section{Contribution of obesity to the development of acute pancreatitis}

The several ways by which obesity increases the risk of acute pancreatitis are summarized in Table 1 and are discussed below:

1. Cholelithiasis: Overweight and obese patients have higher incidence of biliary disease $\left[18^{\mathbf{m}}, 19 \mathbf{m}\right.$ ] and pancreatitis [19 $]$. Biliary disease causes acute pancreatitis by stones, sludge, or micro-lithiasis in the biliopancreatic passages either causing bile reflux or increasing pancreatic duct pressure [20]. Obesity may impact gallstone formation by multiple mechanisms. A high-fat western diet may predispose to cholesterol-rich crystals or stones in the bile [21] by increasing cholesterol crystal number [22] or growth [23]. This is supported by obese children with biliary pancreatitis having a higher likelihood of stones than sludge [24]. Additional factors may include the decrease in circulating bile acids, and gall bladder stasis from increasing intervals between meals in an attempt to lose weight or prevent obesity $[25,26]$. Obesity may also affect diagnosis of gallstones, as one study reports a decreased sensitivity of magnetic resonance cholangio-pancreatography in detecting gallstone in obese and overweight patients [27].

2. Hypertriglyceridemia (HTG): HTG is associated with obesity and pancreatitis $[28,29]$. Obesity can unmask primary HTG from genetic causes [ $\left[30^{-}\right.$, and is a risk factor for secondary HTG [31 ]. Weight loss, a treatment modality for HTG [32], is an additional risk factor pancreatitis. Among the potential mechanisms of HTG-induced pancreatitis is the insolubility of the lipid triglycerides in the aqueous environment of blood resulting in microthrombi in the pancreatic vasculature causing ischemia and pancreatic infarction. Interestingly, hypertriglyceridemic pancreatitis tends to be severe [33-35] more often than other causes. This may be because of the lipolysis of circulating triglycerides, 
and the resulting unsaturated fatty acids (UFAs) generated causing SAP, as discussed below.

3. Diabetes: Diabetes mellitus type-2 and obesity are intimately associated. Although diabetes may occur as an acute pancreatitis complication from loss of pancreatic mass or function, diabetes mellitus type-2 may increase acute pancreatitis risk via HTG [36 ${ }^{\boldsymbol{n}}$, cholelithiasis [37 ${ }^{\mathbf{n}}$ ] because of a high-fat diet, and incretin-based treatments - perhaps via $\beta$-cell hypertrophy[38]. Although the exact mechanisms are unknown, islet cell hypertrophy such as in nesidioblastosis can result in duct obstruction and pancreatitis [39-41 $\boldsymbol{\square}^{-42}$. Some studies and metaanalyses support the increased acute pancreatitis risk [43 $\left.\boldsymbol{\square}_{-45^{\boldsymbol{\square}}}, 46\right]$ with either, for example, glucagon-like peptide-1 receptor agonists[47] or dipeptideyl peptidase-4 inhibitors [48]; however, others refute this [49-51 $\left.\boldsymbol{\square}^{\mathbf{\square}}, 52\right]$. The data on acute pancreatitis outcomes in diabetic patients are inconsistent, with some reporting worse [53] and others showing better outcomes [54] and need further studies.

4. Therapeutic interventions for obesity: The morbidity associated with obesity has resulted in several interventions to prevent or reverse it. Although strong proof that medical therapies for obesity are associated with pancreatitis is lacking, the body of literature associating surgical or minimally invasive interventions with pancreatitis is fairly strong and is discussed below:

a. Bariatric surgery: Surgical weight loss options include Roux-en-Y gastric bypass (RYGB) surgery, laparoscopic gastric banding, and sleeve gastrectomy. Pancreatitis may occur during the extended postoperative period in $0.2-1 \%$ cases of laparoscopic RYGB surgery without cholelithiasis noted at operation $[55,56]$. Gallstones and pancreatitis amount to 5 and $10 \%$ of all complications in the first 3 years after surgery [57 ${ }^{\boldsymbol{\square}}$. Although the risk of pancreatitis is higher than the general population $(0.02-0.04 \%)$, it is too low to warrant a cholecystectomy without concomitant gallstones or cholecystitis. The main mechanisms attributed to the increased risk of gallstones and pancreatitis are postoperative rapid weight loss [56] and gallbladder stasis. Other mechanisms hypothesized to cause pancreatitis include ampullary stenosis, sphincter of oddi dysfunction, and closed-loop obstruction [58 ${ }^{\square}$ and nesidioblastosis [59,60]. Hyperamylasemia and lipasemia are noted in a large proportion of patients with postoperative small bowel obstruction of the biliopancreatic limb [61] without a clinical diagnosis of pancreatitis.

b. Duodeno-jejunal bypass liner (DJBL). Case report series show pancreatitis to occur in $2-3 \%$ of patients with a DJBL $[62,63]$. The pathophysiology includes edema or physical blockage of the ampulla of Vater by food material accumulating between the duodenum and the liner of the DJBL, pressure from the device causing reflux of duodenal 
contents or blocking flow from the pancreatic duct, or the DJBL's anchor migrating to obstruct the ampulla.

c. Gastric balloons: There are several reports of acute pancreatitis following placement of gastric balloons for weight loss [64,65,66 $]$. The largest series includes 301 patients followed for 6 months, two of whom developed pancreatitis [67]. Pancreatitis may occur from dislodgement or pressure on the pancreas. Interestingly, an emerging therapy for pancreatitis is a rapidly reversible cooling balloon placed in the stomach [68 $]$, which cools the pancreas transgastrically and may slow the numerous mechanisms active in pancreatitis simultaneously.

\section{Role of obesity in severity of acute pancreatitis}

The severity of acute pancreatitis is typically unrelated to the acute pancreatitis cause [6972]. Unlike subcutaneous fat, which rarely impacts the severity of acute pancreatitis [73 obesity associated increase in visceral fat in or around the pancreas can worsen acute pancreatitis outcomes $[8,14,74,75]$ (Fig. 1A, B). This can present as hypocalcemia earlier, or as organ failure later in the disease course (Fig. 1C, D). The resulting damage to visceral fat, described as fat necrosis, is a part of radiographic criteria for pancreatitis severity $[76,77]$ and the revised Atlanta criteria [78]. Additionally, obesity increases the risk of HTG both preceding and during an attack of pancreatitis [ $79 \mathbf{m}^{-}$. Therefore, obesity can worsen pancreatitis.

Patterns of severe pancreatitis noted in obesity:

1. Local pancreatic necrosis: About $95 \%$ of necrotizing pancreatitis involves fat necrosis and pancreatic necrosis [76-78,80,81], with isolated pancreatic parenchymal necrosis occurring in less than $5 \%$ of cases [81]. In obesity, adipocytes within the pancreas (i.e., intrapancreatic fat) increase with BMI $[82,83]$ and are dispersed fairly uniformly [84] adjacent to the basolateral membranes of the lipase rich exocrine pancreatic acinar cells (Fig. 2). Although these triglyceride-rich adipocytes are normally not subject to lipolysis because of the apically polarized secretion from acinar cells, this homeostasis is disrupted during acute pancreatitis. The basolateral release of digestive enzymes including lipases into adipocytes damages them $[85,86]$ and hydrolyzes their triglyceride which forms more than $80 \%$ of adipocyte mass [87-89]. The composition of this triglyceride is predominantly unsaturated in obesity $[83,90 \mathbf{m}$. This hydrolysis causes UFAs release from the damaged adipocytes, which in turn causes necrosis of acinar cells by inhibiting mitochondrial complexes I and V [83]. This vicious lipolytic flux causes further acinar damage; perpetuating necrotizing pancreatitis via lipase leak-mediated UFA release. In contrast, adipocyte mass in chronic pancreatitis is unrelated to BMI, and is surrounded by fibrosis, which prevents the lipolytic flux between the two compartments [86] and thereby SAP.

2. Systemic injury including organ failure: Although about $80 \%$ cases of pancreatic necrosis occurs with peripancreatic fat (PPF) necrosis [81,91], about $10-15 \%$ of cases of moderate-to-severe pancreatitis have PPF necrosis without pancreatic 
parenchymal necrosis [81,91] (Fig. 1b-d). PPF close to the pancreas, such as perinephric, mesenteric, perisplenic is prone to lipolysis. When extensive, PPF necrosis alone can result in moderate acute pancreatitis to SAP [81,91-93] (Fig. 1b-d, Fig. 2) and sometimes mortality [94-96] via systemic injury including shock, renal, and respiratory failure from UFA toxicity $\left[90^{\mathbf{m}}\right]$.

\section{Mechanisms by which obesity may exacerbate pancreatitis}

In obesity, adipose tissue can exceed $30 \%$ of body weight [97] with visceral fat comprising more than $3 \%$ of body weight [98]. More than $80 \%$ of adipocyte mass is triglyceride [8789], which when hydrolyzed by the leaked lipases can generate three fatty acids from each cleaved triglyceride molecule. Studies analyzing the composition of pancreatic necrosis collections, report these to be enriched in the UFAs oleic (C18:1) and linoleic acid (C18 : 2) $[83,90$,99]. Additionally, cytokines such as interleukin (IL)- $1 \beta$ and IL- 8 have been shown to be increased in necrotic collections $\left[90^{\mathbf{m}}\right]$.

1. Lipid mediators: UFAs is the major class of lipid mediators in SAP. In-vitro UFA toxicity to pancreatic cells was shown by Mossner et al. [100] and the clinical, in-vivo relevance of these was shown recently by Navina et al. [83] [90 $101,102 \mathbf{m}$ ]. The concentration of UFAs generated in fat necrosis can be in the millimolar range [83,90 ,99] and high concentrations are noted in the sera of patients with SAP $[103,104]$. Being polar, UFAs are normally bound by calcium, resulting in their saponification and inactivation in fat necrosis. This can result in the hypocalcemia noted during SAP (Fig. 1c), which is part of Ranson et al.'s [105], Japanese severity score [106] and the recently validated [107] Glasgow criteria [108]. The remaining unbuffered nonesterified UFAs can increase inflammatory mediators such as tumor necrosis factor (TNF-a), CXC ligand 1 (CXCL1), and CXCL2, and cause necrosis by reducing ATP levels via inhibiting mitochondrial complexes I and V [83], thus worsening acute pancreatitis. This damage is noted within the pancreas as perifat acinar necrosis [83,102 $\mathbf{m}$, forming half of all parenchymal necrosis, and systemically as renal tubular apoptosis associated with renal failure, and dead cells in lung alveoli $[83,90 \mathbf{m}$, 101,102 ] similar to acute respiratory distress syndrome [109,110] (Fig. 2). Thus uncontrolled UFA release by being proinflammatory and causing cell death seems to be the orchestrator of the cytokine response and release of damageassociated molecular patterns (DAMPs) from dying cells. These are discussed below:

2. Proteins: The proteins whose concentrations are altered in the circulation of patients with SAP have been studied as therapeutic targets in SAP. Chief among these are activated protein $C$ which is reduced, or cytokines like IL-6 [111-114], IL-1 $\beta$ [115], IL-8 [111,114,116], monocyte chemotactic protein-1 [117], TNF-a, [112] or adipokines, including resistin and visfatin [76,118] which are increased in SAP. The clinical trials replacing activated protein $\mathrm{C}$, whereas showing its safety [119], have not shown a clear benefit of improving outcomes in SAP [120]. Similarly, although cytokines are markers of SAP, conclusive proof of them mediating acute pancreatitis severity is lacking. A recent study showed that 
IL-1 $\beta$ and IL- 8 cause fever and an increase in leukocyte infiltration into the pancreas and lungs; however, they did not worsen acute pancreatitis, as evidenced by the lack of pancreatic necrosis, systemic injury, or mortality [90. Moreover inhibition of triglyceride lipolysis by orlistat reduced serum UFAs, IL-1 $\beta$, and IL- 8 , and prevented organ failure and mortality [90 ${ }^{\mathbf{m}}$ ]. Interestingly, some studies ascribe a protective role to IL-6, IL-8, and TNF-a [121-123]. These findings along with the inability of cytokines to induce outcomes relevant to SAP [122-126], and the unclear benefit of anti-TNF-a therapies in acute pancreatitis [127-131], make cytokines unfavorable therapeutic targets in obesity-associated SAP.

3. DAMPs: DAMPs are released when there is cell injury such as in necrosis. DAMPs include high-mobility group box 1 (HMGB1), the soluble receptor for advanced glycation end products, nuclear components (e.g., DNA, nucleosomes, histones), belonging to the S100 protein family, ATP, and extracellular matrix components such as hyaluronan fragments. Hoque et al. [132] first showed the requirement of the DAMP receptors TLR9 (agonist; nucleic acids) and P2X7 (agonist; ATP) in caerulein pancreatitis. Intracellular HMGB1 was later shown to be protective in L-arginine and caerulein pancreatitis [133]. Although serum HMGB1 [134], soluble receptor for advanced glycation end products [135], histone $\left[136^{\mathbf{m}}\right.$ ], and nucleosome [137 ${ }^{\mathbf{m}}$ levels correlate with human acute pancreatitis severity; it remains unclear whether DAMPs are markers or mediators of SAP outcomes and conclusive studies on them inducing end points that are clinically relevant to SAP need to be done.

\section{Potential therapies for obesity related severe acute pancreatitis}

1. Choice of intravenous (IV) fluids: As the initial study by Wu et al. [138] reporting Lactated Ringer's reduces SIRS and C-reactive protein more than saline in acute pancreatitis patients, other studies have shown similar results $\left[139,140{ }^{\square}\right.$. Potential beneficial mechanisms of Lactated Ringer's include 1) the $3 \mathrm{mEq} / \mathrm{l}$ calcium it contains, 2) Lactated Ringer's being buffered whereas saline is not, and 3) the lactate in Lactated Ringer's being a G-protein receptior (GPR81) agonist and thereby reducing inflammasome and nuclear factor kappa $B$ activation [141]. It should be noted that the role of GPR81 has not been studied in obese mice or in the context of organ failure. Additionally, saline has no buffering capacity and is unlikely to influence blood $\mathrm{pH}$. Hypocalcemia is a known complication of SAP $[105,106,108]$ (Fig. 1c). A study comparing extracellular calcium replacement to $\mathrm{pH} 7.4$ buffered lactate showed improved outcomes in the calcium group [142]. Thus Lactated Ringer's benefit is most likely via replacing extracellular calcium which can bind and saponify UFAs.

2. Lipase inhibitors: Therapeutic use of lipase inhibitors improves outcomes in etiologically different lethal models of experimental acute pancreatitis in obesity $[83,102,143]$. This includes a reduction in mortality, severe pancreatic necrosis, renal, and respiratory failure. These benefits are also noted in lethal acute pancreatitis induced concurrently with administration of triglycerides 
containing UFAs found in human pancreatic necrosis [90 $\left.{ }^{\mathbf{m}}, 101\right]$. However, the only Food and Drug Administration-approved formulation of the lipase inhibitor, orlistat is oral, which is poorly absorbed $(<1 \%)$ and is used worldwide as the counter drug for weight loss. For use in SAP, orlistat requires a special parenteral formulation $\left[102^{\square}\right.$ ], which would be off-label use of the drug. The few case reports of orlistat and pancreatitis [144-146] over the last decade show a latency period varying from 2 to 10 days and there is no rechallenging data. The evidence against orlistat is thus class III [147], and is likely coincidental given orlistat's widespread use and the fact that about $20 \%$ of acute pancreatitis is idiopathic. These points reinforce the urgent need to develop better agents for use in acute pancreatitis.

\section{CONCLUSION}

The growing pandemic of obesity has increased acute pancreatitis's incidence and severity. The increase in incidence is because of increased risk of gallstones, HTG, medications, and weight loss interventions. Obesity worsens acute pancreatitis severity by allowing unregulated lipolysis of visceral fat enriched in unsaturated triglyceride, thus releasing UFAs which inhibit mitochondrial complexes I and V, cause necrosis, and worsen acute pancreatitis. Lactated Ringer's benefit over saline as an IV fluid for managing acute pancreatitis because of the calcium it contains, and whereas definitive measures to prevent and neutralize UFA toxicity are needed, parenteral formulations of orlistat remain a potential option.

\section{Acknowledgements}

The contents of the manuscript are solely the responsibility of the authors and do not necessarily represent the official view of DOA, NIDDK.

Financial support and sponsorship

Supported by Grant number PR151612 from the Department of Army (DOA) (VPS), award number R01DK092460, R01DK100358 (VPS) from the National Institute of Diabetes and Digestive and Kidney Diseases (NIDDK). The funders had no role in study design, data collection and analysis, decision to publish, or preparation of the manuscript.

\section{REFERENCES AND RECOMMENDED READING}

Papers of particular interest, published within the annual period of review, have been highlighted as:

of special interest

- of outstanding interest

1. Ogden CL, Carroll MD, Curtin LR, et al. Prevalence of overweight and obesity in the United States, 1999-2004. JAMA 2006; 295:1549-1555. [PubMed: 16595758]

2. Peery AF, Crockett SD, Barritt AS, et al. Burden of gastrointestinal, liver, and pancreatic diseases in the United States. Gastroenterology 2015; 149:1731.e3-1741.e3. [PubMed: 26327134]

3. Brown A, Young B, Morton J, et al. Are health related outcomes in acute pancreatitis improving? An analysis of national trends in the U.S. from 1997 to 2003. JOP 2008; 9:408-414. [PubMed: 18648131] 
4. Abu Hilal M, Armstrong T. The impact of obesity on the course and outcome of acute pancreatitis. Obes Surg 2008; 18:326-328. [PubMed: 18202895]

5. Papachristou GI, Papachristou DJ, Avula H, et al. Obesity increases the severity of acute pancreatitis: performance of APACHE-O score and correlation with the inflammatory response. Pancreatology 2006; 6:279-285. [PubMed: 16636600]

6. Porter KA, Banks PA. Obesity as a predictor of severity in acute pancreatitis. Int J Pancreatol 1991; 10:247-252. [PubMed: 1787336]

7. Shin KY, Lee WS, Chung DW, et al. Influence of obesity on the severity and clinical outcome of acute pancreatitis. Gut Liver 2011; 5:335-339. [PubMed: 21927663]

8. O'Leary DP, O'Neill D, McLaughlin P, et al. Effects of abdominal fat distribution parameters on severity of acute pancreatitis. World J Surg 2012; 36:1679-1685. [PubMed: 22491816]

9. Sempere L, Martinez J, de Madaria E, et al. Obesity and fat distribution imply a greater systemic inflammatory response and a worse prognosis in acute pancreatitis. Pancreatology 2008; 8:257-264. [PubMed: 18497538]

10. Evans AC, Papachristou GI, Whitcomb DC. Obesity and the risk of severe acute pancreatitis. Minerva Gastroenterol Dietol 2010; 56:169-179. [PubMed: 20485254]

11. Chen SM, Xiong GS, Wu SM. Is obesity an indicator of complications and mortality in acute pancreatitis? An updated meta-analysis. J Dig Dis 2012; 13:244-251. [PubMed: 22500786]

12. Krishna SG, Behzadi J, Hinton A, et al. Effects of bariatric surgery on outcomes of patients with acute pancreatitis. Clin Gastroenterol Hepatol 2016; 14:1001.e5-1010.e5. [PubMed: 26905906]

13. Krishna SG, Hinton A, Oza V, et al. Morbid obesity is associated with adverse clinical outcomes in acute pancreatitis: a propensity-matched study. Am J Gastroenterol 2015; 110:1608-1619. [PubMed: 26482857] The nationwide study exemplifies the increased severity of pancreatitis in morbidly obese patients.

14. Sadr-Azodi O, Orsini N, Andren-Sandberg A, Wolk A. Abdominal and total adiposity and the risk of acute pancreatitis: a population-based prospective cohort study. Am J Gastroenterol 2013; 108:133-139. [PubMed: 23147519]

15. Ng M, Fleming T, Robinson M, et al. Global, regional, and national prevalence of overweight and obesity in children and adults during 1980-2013: a systematic analysis for the Global Burden of Disease Study 2013. Lancet 2014; 384:766-781. [PubMed: 24880830]

16. Du P, Wang HJ, Zhang B, et al. Prevalence of abdominal obesity among Chinese adults in 2011. J Epidemiol 2017; 27:282-286. [PubMed: 28427831]

17. Spanier B, Bruno MJ, Dijkgraaf MG. Incidence and mortality of acute and chronic pancreatitis in the Netherlands: a nationwide record-linked cohort study for the years 1995-2005. World J Gastroenterol 2013; 19:3018-3026. [PubMed: 23716981]

18. Radmard AR, Merat S, Kooraki S, et al. Gallstone disease and obesity: a population-based study on abdominal fat distribution and gender differences. Ann Hepatol 2015; 14:702-709. [PubMed: 26256899] These studies demonstrate the increased risk of cholelithiasis with obesity.

19. Flint R Differences in acute general surgical admissions between obese or overweight patients

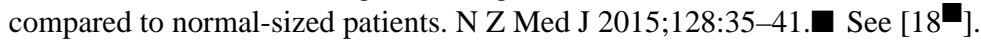

20. Lerch MM, Gorelick FS. Models of acute and chronic pancreatitis. Gastroenterology 2013; 144:1180-1193. [PubMed: 23622127]

21. Lee JY, Keane MG, Pereira S. Diagnosis and treatment of gallstone disease. Practitioner 2015; 259:15-19.

22. Janowitz P, Wechsler JG, Swobodnik W, et al. Nucleation time and lithogenic index in obese patients and in patients with cholecystolithiasis. Z Gastroenterol 1988; 26:750-754. [PubMed: 3245253]

23. Whiting MJ, Watts J. Supersaturated bile from obese patients without gallstones supports cholesterol crystal growth but not nucleation. Gastroenterology 1984; 86:243-248. [PubMed: 6690352]

24. Ma MH, Bai HX, Park AJ, et al. Risk factors associated with biliary pancreatitis in children. J Pediatr Gastroenterol Nutr 2012; 54:651-656. [PubMed: 22002481]

25. Hofmann AF. Pathogenesis of cholesterol gallstones. J Clin Gastroenterol 1988; 10(Suppl 2):S1S11.

Curr Opin Gastroenterol. Author manuscript; available in PMC 2019 July 19. 
26. Weinsier RL, Ullmann DO. Gallstone formation and weight loss. Obes Res 1993; 1:51-56. [PubMed: 16350561]

27. Coban G, Yildirim E, Gokturk S, et al. Body mass index, cholecystitis, cholelithiasis, pancreatitis and imaging of common bile duct stones. Am J Med Sci 2014; 347:364-369. [PubMed: 23838577]

28. Pitha J, Kovar J, Blahova T. Fasting and nonfasting triglycerides in cardiovascular and other diseases. Physiol Res 2015; 64(Suppl 3): S323-S330. [PubMed: 26680665]

29. Vipperla K, Somerville C, Furlan A, et al. Clinical profile and natural course in a large cohort of patients with hypertriglyceridemia and pancreatitis. J Clin Gastroenterol 2017; 51:77-85. [PubMed: 27322530]

30. Shah AS, Wilson DP. Primary hypertriglyceridemia in children and adolescents. J Clin Lipidol 2015; 9:S20-S28. [PubMed: 26343209] These articles show examples of studies in which primary HTG is unmasked by obesity along with obesity increasing the risk of HTG.

31. Blackett PR, Wilson DP, McNeal CJ. Secondary hypertriglyceridemia in children and adolescents. J Clin Lipidol 2015; 9:S29-S40. [PubMed: 26343210] $\mathbf{\square}$ See [30].

32. Kushner PA, Cobble ME. Hypertriglyceridemia: the importance of identifying patients at risk. Postgrad Med 2016; 128:848-858. [PubMed: 27710158]

33. Lloret Linares C, Pelletier AL, Czernichow S, et al. Acute pancreatitis in a cohort of 129 patients referred for severe hypertriglyceridemia. Pancreas 2008; 37:.

34. Deng LH, Xue P, Xia Q, et al. Effect of admission hypertriglyceridemia on the episodes of severe acute pancreatitis. World J Gastroenterol 2008; 14:4558-4561. [PubMed: 18680239]

35. Dominguez-Munoz JE, Malfertheiner P, Ditschuneit HH, et al. Hyperlipidemia in acute pancreatitis. Relationship with etiology, onset, and severity of the disease. Int J Pancreatol 1991; 10:261-267. [PubMed: 1787337]

36. Albai O, Roman D, Frandes M Hypertriglyceridemia, an important and independent risk factor for acute pancreatitis in patients with type 2 diabetes mellitus. Ther Clin Risk Manag 2017; 13:515522. [PubMed: 28450786]

37. Monami M, Nreu B, Scatena A, et al. Safety issues with glucagon-like peptide-1 receptor agonists (pancreatitis, pancreatic cancer, and cholelithiasis): data from randomized controlled trials. Diabetes Obes Metab 2017. The 2 articles above detail how diabetes may increase the risk of pancreatitis - that is, via HTG, cholelithiasis.

38. Mondragon A, Davidsson D, Kyriakoudi S, et al. Divergent effects of liraglutide, exendin-4, and sitagliptin on beta-cell mass and indicators of pancreatitis in a mouse model of hyperglycaemia. PLoS One 2014; 9:e104873. [PubMed: 25119717]

39. Kobayashi T, Manivel JC, Bellin MD, et al. Correlation of pancreatic histopathologic findings and islet yield in children with chronic pancreatitis undergoing total pancreatectomy and islet autotransplantation. Pancreas 2010; 39:57-63. [PubMed: 19745778] $\square$ These articles support an increase in risk of pancreatitis with incretin-based therapies.

40. Novaes G, Chetto-de-Queiroz A, De-Carvalho-Cardoso C, et al. Nesidioblastosis associated with chronic experimental pancreatitis produced by a scorpion toxin, tityustoxin, in rats. Braz J Med Biol Res 1990; 23:1149-1151. [PubMed: 2133023] $\mathbf{\square}$ See [39].

41. Odaira C, Choux R, Payan MJ, et al. Chronic obstructive pancreatitis, nesidioblastosis, and small endocrine pancreatic tumor. Dig Dis Sci1987; 32:770-774. See [39 ].

42. Wig JD, Nayak NC, Kumar S, et al. A 20-year-old man with recurrent abdominal pain and vomiting since the age of 5 years. Familial chronic pancreatitis with nesidioblastosis and hyperinsulinaemic hypoglycaemia. Natl Med J India 2008; 21:307-312. [PubMed: 19691221]

43. Knapen LM, de Jong RG, Driessen JH, et al. Use of incretin agents and risk of acute and chronic pancreatitis: a population-based cohort study. Diabetes Obes Metab 2017; 19:401-411. [PubMed: 27883260]

44. Roshanov PS, Dennis BB. Incretin-based therapies are associated with acute pancreatitis: metaanalysis of large randomized controlled trials. Diabetes Res Clin Pract 2015; 110:e13-e17. [PubMed: 26643128]

45. Lai YJ, Hu HY, Chen HH, Chou P. Dipeptidyl peptidase-4 inhibitors and the risk of acute pancreatitis in patients with type 2 diabetes in Taiwan: a population-based cohort study. Medicine 
(Baltimore) 2015; 94:e1906. [PubMed: 26512613] $\mathbf{~ T h e ~ t h r e e ~ a r t i c l e s ~ a b o v e ~ s u p p o r t ~ a n ~ i n c r e a s e ~}$ in risk of pancreatitis with incretin-based therapies.

46. Funch D, Gydesen H, Tornoe K, et al. A prospective, claims-based assessment of the risk of pancreatitis and pancreatic cancer with liraglutide compared to other antidiabetic drugs. Diabetes Obes Metab 2014; 16:273-275. [PubMed: 24199745]

47. Singh S, Chang HY, Richards TM, et al. Glucagonlike peptide 1-based therapies and risk of hospitalization for acute pancreatitis in type 2 diabetes mellitus: a population-based matched casecontrol study. JAMA Intern Med 2013; 173:534-539. [PubMed: 23440284]

48. Rehman MB, Tudrej BV, Soustre J, et al. Efficacy and safety of DPP-4 inhibitors in patients with type 2 diabetes: meta-analysis of placebo-controlled randomized clinical trials. Diabetes Metab 2017; 43:48-58. [PubMed: 27745828]

49. Liao KF, Lin CL, Lai SW, Chen WC. Sitagliptin use and risk of acute pancreatitis in type 2 diabetes mellitus: a population-based case-control study in Taiwan. Eur J Intern Med 2016; 27:7679. [PubMed: 26433909]

50. Storgaard H, Cold F, Gluud LL, et al. Glucagon-like peptide-1 receptor agonists and risk of acute pancreatitis in patients with type 2 diabetes. Diabetes Obes Metab 2017; 19:906-908. [PubMed: 28105738]

51. Azoulay L, Filion KB, Platt RW, et al. Association between incretin-based drugs and the risk of acute pancreatitis. JAMA Intern Med 2016; 176:1464-1473. [PubMed: 27479930] $\mathbf{\square}$ The three articles above do not support an increased risk of acute pancreatitis with incretinbased therapies.

52. Li L, Shen J, Bala MM, et al. Incretin treatment and risk of pancreatitis in patients with type 2 diabetes mellitus: systematic review and meta-analysis of randomised and non-randomised studies. BMJ 2014; 348:g2366. [PubMed: 24736555]

53. Huh JH, Jeon H, Park SM, et al. Diabetes mellitus is associated with mortality in acute pancreatitis. J Clin Gastroenterol 2016.

54. Mendez-Bailon M, de Miguel Yanes JM, Jimenez-Garcia R, et al. National trends in incidence and outcomes of acute pancreatitis among type 2 diabetics and non-diabetics in Spain (2001-2011). Pancreatology 2015; 15:64-70. [PubMed: 25500341]

55. Warschkow R, Tarantino I, Ukegjini K, et al. Concomitant cholecystectomy during laparoscopic Roux-en-Y gastric bypass in obese patients is not justified: a meta-analysis. Obes Surg 2013; 23:397-407. [PubMed: 23315094]

56. Kumaravel A, Zelisko A, Schauer P, et al. Acute pancreatitis in patients after bariatric surgery: incidence, outcomes, and risk factors. Obes Surg 2014; 24:2025-2030. [PubMed: 24972683]

57. Chang J, Corcelles R, Boules M, et al. Predictive factors of biliary complications after bariatric surgery. Surg Obes Relat Dis 2016; 12:1706-1710. [PubMed: 26948453] $\mathbf{\square}$ The article describes the risk of gallstones in the 3-year postoperative period after gastric bypass surgery.

58. Arapis K, Tammaro P, Goujon G, et al. Elevated plasma pancreatic enzyme concentrations after Roux-en-Y gastric bypass may indicate closed loop obstruction. Ann R Coll Surg Engl 2017; 99:e62-e64. [PubMed: 27791421] — These studies describe the high prevalence of serum amylase, lipase elevation after RYGB surgery.

59. Service GJ, Thompson GB, Service FJ, et al. Hyperinsulinemic hypoglycemia with nesidioblastosis after gastric-bypass surgery. N Engl J Med 2005; 353:249-254. [PubMed: 16034010]

60. Unal B, Uzun OC, Bassorgun CI, et al. A rare complication of gastric bypass (weight loss) surgery: nesidioblastosis. Int J Surg Pathol 2015; 23:68-70. [PubMed: 25326474]

61. Spector D, Perry Z, Shah S, et al. Roux-en-Y gastric bypass: hyperamylasemia is associated with small bowel obstruction. Surg Obes Relat Dis 2015; 11:38-43. [PubMed: 25264325]

62. Betzel B, Koehestanie P, Aarts EO, et al. Safety experience with the duodenal-jejunal bypass liner: an endoscopic treatment for diabetes and obesity. Gastrointest Endosc 2015; 82:845-852.

[PubMed: 25952090] This is the largest case series of the complications associated with the use of DJBL.

63. Betzel B, Homan J, Aarts E, et al. Acute pancreatitis as an adverse event in patients with the duodenal-jejunal bypass liner. Endoscopy 2015; 47:1050-1053. [PubMed: 26021308] 
64. Mohammed AE, Benmousa A. Acute pancreatitis complicating intragastric balloon insertion. Case Rep Gastroenterol 2008; 2:291-295. [PubMed: 21490858]

65. Holland S, Bach D, Duff J. Balloon therapy for obesity: when the balloon bursts. J Can Assoc Radiol 1985; 36:347-349. [PubMed: 4086508]

66. Issa I, Taha A, Azar C. Acute pancreatitis caused by intragastric balloon: a case report. Obes Res

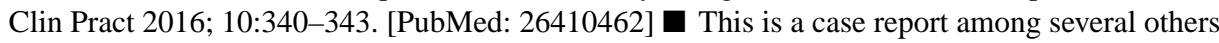
on acute pancretitis being caused by use of a gastric balloon for inducing weight loss.

67. Almeghaiseeb ES, Ashraf MF, Alamro RA, et al. Efficacy of intragastric balloon on weight reduction: Saudi perspective. World J Clin Cases 2017; 5:140-147. [PubMed: 28470006]

68. De Oliverira C, Patel K, Mishra V, et al. Transgastric therapeutic pancreatic hypothermia as a novel therapy for acute pancreatitis (AP). Pancreas 2016;45:1502. This studies pancreatic cooling via a cooled gastric balloon to therapeutically improve acute pancreatitis outcomes.

69. Chen CH, Dai CY, Hou NJ, et al. Etiology, severity and recurrence of acute pancreatitis in southern Taiwan. J Formos Med Assoc 2006; 105:550-555. [PubMed: 16877234]

70. Sekimoto M, Takada T, Kawarada Y, et al. JPN Guidelines for the management of acute pancreatitis: epidemiology, etiology, natural history, and outcome predictors in acute pancreatitis. J Hepatobiliary Pancreat Surg 2006; 13:10-24. [PubMed: 16463207]

71. Xin MJ, Chen H, Luo B, Sun JB. Severe acute pancreatitis in the elderly: etiology and clinical characteristics. World J Gastroenterol 2008; 14:2517-2521. [PubMed: 18442198]

72. Vidarsdottir H, Moller PH, Thorarinsdottir H, Bjornsson ES. Acute pancreatitis: a prospective study on incidence, etiology, and outcome. Eur J Gastroenterol Hepatol 2013; 25:1068-1075. [PubMed: 23839162]

73. Yoon SB, Choi MH, Lee IS, et al. Impact of body fat and muscle distribution on severity of acute pancreatitis. Pancreatology 2017; 17:188-193. [PubMed: 28190685] $\mathbf{\square}$ This study shows that it is the visceral fat and not the subcutaneous fat that is associated with an increased severity of acute pancreatitis.

74. Yashima $\mathrm{Y}$, Isayama $\mathrm{H}$, Tsujino T, et al. A large volume of visceral adipose tissue leads to severe acute pancreatitis. J Gastroenterol 2011; 46:1213-1218. [PubMed: 21805069]

75. Funnell IC, Bornman PC, Weakley SP, et al. Obesity: an important prognostic factor in acute pancreatitis. Br J Surg 1993; 80:484-486. [PubMed: 8495317]

76. Schaffler A, Hamer O, Dickopf J. Admission resistin levels predict peripancreatic necrosis and clinical severity in acute pancreatitis. Am J Gastroenterol 2010; 105:2474-2484. [PubMed: 20648005]

77. Balthazar EJ, Robinson DL, Megibow AJ, Ranson JH. Acute pancreatitis: value of CT in establishing prognosis. Radiology 1990; 174:331-336. [PubMed: 2296641]

78. Banks PA, Bollen TL, Dervenis C, et al. Classification of acute pancreatitis 2012: revision of the Atlanta classification and definitions by international consensus. Gut 2013; 62:102-111. [PubMed: 23100216]

79. Nawaz H, Koutroumpakis E, Easler J, et al. Elevated serum triglycerides are independently associated with persistent organ failure in acute pancreatitis.Am J Gastroenterol 2015; 110:14971503. [PubMed: 26323188] - This study shows that obesity may increase pancreatitis severity by increasing serum triglycerides both preceding and during an attack of pancreatitis.

80. Freeman ML, Werner J, van Santvoort HC, et al., International Multidisciplinary Panel of Speakers and Moderators. Interventions for necrotizing pancreatitis: summary of a multidisciplinary consensus conference. Pancreas 2012; 41:1176-1194. [PubMed: 23086243]

81. Bakker OJ, van Santvoort H, Besselink MG, et al., Dutch Pancreatitis Study Group. Extrapancreatic necrosis without pancreatic parenchymal necrosis: a separate entity in necrotising pancreatitis? Gut 2013; 62:1475-1480. [PubMed: 22773550]

82. Saisho Y, Butler AE, Meier JJ, et al. Pancreas volumes in humans from birth to age one hundred taking into account sex, obesity, and presence of type-2 diabetes. Clin Anat 2007; 20:933-942. [PubMed: 17879305]

83. Navina S, Acharya C, DeLany JP, et al. Lipotoxicity causes multisystem organ failure and exacerbates acute pancreatitis in obesity. Sci Transl Med 2011; 3:107ra110. 
84. Matsumoto S, Mori H, Miyake H, et al. Uneven fatty replacement of the pancreas: evaluation with CT. Radiology 1995; 194:453-458. [PubMed: 7824726]

85. Aho HJ, Sternby B, Kallajoki M, Nevalainen TJ. Carboxyl ester lipase in human tissues and in acute pancreatitis. Int J Pancreatol 1989; 5:123-134. [PubMed: 2689525]

86. Acharya C, Cline RA, Jaligama D, et al. Fibrosis reduces severity of acute-on-chronic pancreatitis in humans. Gastroenterology 2013; 145:466-475. [PubMed: 23684709]

87. Ren J, Dimitrov I, Sherry AD, Malloy CR. Composition of adipose tissue and marrow fat in humans by 1H NMR at 7 Tesla. J Lipid Res 2008; 49:2055-2062. [PubMed: 18509197]

88. Thomas LW. The chemical composition of adipose tissue of man and mice. Q J Exp Physiol Cogn Med Sci 1962; 47:179-188. [PubMed: 13920823]

89. Garaulet M, Hernandez-Morante JJ, Lujan J, et al. Relationship between fat cell size and number and fatty acid composition in adipose tissue from different fat depots in overweight/obese humans. Int J Obes (London) 2006; 30:899-905. [PubMed: 16446749]

90. Noel P, Patel K, Durgampudi C, et al. Peripancreatic fat necrosis worsens acute pancreatitis independent of pancreatic necrosis via unsaturated fatty acids increased in human pancreatic necrosis collections. Gut 2016; 65:100-111. [PubMed: 25500204] ש This shows human pancreatic necrosis collections are enriched in unsaturated fatty acids which cause multi-system organ failure and inflammatory cell death.

91. Koutroumpakis E, Dasyam AK, Furlan A, et al. Isolated peripancreatic necrosis in acute pancreatitis is infrequent and leads to severe clinical course only when extensive: a prospective study from a US tertiary center. J Clin Gastroenterol 2016; 50:589-595. [PubMed: 26828244]

92. Singh VK, Bollen TL, Wu BU, et al. An assessment of the severity of interstitial pancreatitis. Clin Gastroenterol Hepatol 2011; 9:1098-1103. [PubMed: 21893128]

93. Bollen TL, Singh VK, Maurer R, et al. A comparative evaluation of radiologic and clinical scoring systems in the early prediction of severity in acute pancreatitis. Am J Gastroenterol 2012; 107:612-619. [PubMed: 22186977]

94. Mutinga M, Rosenbluth A, Tenner SM, et al. Does mortality occur early or late in acute pancreatitis? Int J Pancreatol 2000; 28:91-95. [PubMed: 11128978]

95. Fu CY, Yeh CN, Hsu JT, et al. Timing of mortality in severe acute pancreatitis: experience from 643 patients. World J Gastroenterol 2007; 13:1966-1969. [PubMed: 17461498]

96. Carnovale A, Rabitti PG, Manes G, et al. Mortality in acute pancreatitis: is it an early or a late event? JOP 2005; 6:438-444. [PubMed: 16186665]

97. International Consortium for Blood Pressure Genome-Wide Association Studies. Ehret GB, Munroe PB, Rice KM, et al. Genetic variants in novel pathways influence blood pressure and cardiovascular disease risk. Nature 2011; 478:103-109. [PubMed: 21909115]

98. Choh AC, Demerath EW, Lee M, et al. Genetic analysis of self-reported physical activity and adiposity: the Southwest Ohio Family Study. Public Health Nutr 2009; 12:1052-1060. [PubMed: 18778532]

99. Panek J, Sztefko K, Drozdz W. Composition of free fatty acid and triglyceride fractions in human necrotic pancreatic tissue. Med Sci Monit 2001; 7:894-898. [PubMed: 11535930]

100. Mossner J, Bodeker H, Kimura W, et al. Isolated rat pancreatic acini as a model to study the potential role of lipase in the pathogenesis of acinar cell destruction. Int J Pancreatol 1992; 12:285-296. [PubMed: 1289421]

101. Durgampudi C, Noel P, Patel K, et al. Acute lipotoxicity regulates severity of biliary acute pancreatitis without affecting its initiation. Am J Pathol 2014; 184:1773-1784. [PubMed: 24854864]

102. Patel K, Trivedi RN, Durgampudi C, et al. Lipolysis of visceral adipocyte triglyceride by pancreatic lipases converts mild acute pancreatitis to severe pancreatitis independent of necrosis

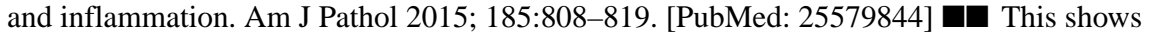
unsaturated fatty acids released by the lipolysis of viseral fat to convert mild AP to severe AP without increasing pancreatic necrosis.

103. Domschke S, Malfertheiner P, Uhl W, et al. Free fatty acids in serum of patients with acute necrotizing or edematous pancreatitis. Int J Pancreatol 1993; 13:105-110. [PubMed: 8501351] 
104. Sztefko K, Panek J. Serum free fatty acid concentration in patients with acute pancreatitis. Pancreatology 2001; 1:230-236. [PubMed: 12120200]

105. Ranson JH, Rifkind KM, Roses DF, et al. Prognostic signs and the role of operative management in acute pancreatitis. Surg Gynecol Obstet 1974; 139:69-81. [PubMed: 4834279]

106. Ueda T, Takeyama Y, Yasuda T, et al. Utility of the new Japanese severity score and indications for special therapies in acute pancreatitis. J Gastroenterol 2009; 44:453-459. [PubMed: 19308309]

107. Mounzer R, Langmead CJ, Wu BU, et al. Comparison of existing clinical scoring systems to predict persistent organ failure in patients with acute pancreatitis. Gastroenterology 2012; 142:1476-1482. [PubMed: 22425589]

108. Blamey SL, Imrie CW, O’Neill J, et al. Prognostic factors in acute pancreatitis. Gut 1984; 25:1340-1346. [PubMed: 6510766]

109. Goncalves-de-Albuquerque CF, Burth P, Silva AR, et al. Oleic acid inhibits lung Na/K-ATPase in mice and induces injury with lipid body formation in leukocytes and eicosanoid production. $\mathrm{J}$ Inflamm (Lond) 2013; 10:34. [PubMed: 24175969]

110. Hussain N, Wu F, Zhu L, et al. Neutrophil apoptosis during the development and resolution of oleic acid-induced acute lung injury in the rat. Am J Respir Cell Mol Biol 1998; 19:867-874. [PubMed: 9843920]

111. Messmann H, Vogt W, Falk W, et al. Interleukins and their antagonists but not TNF and its receptors are released in post-ERP pancreatitis. Eur J Gastroenterol Hepatol 1998; 10:611-617. [PubMed: 9855088]

112. Brivet FG, Emilie D, Galanaud P. Pro- and anti-inflammatory cytokines during acute severe pancreatitis: an early and sustained response, although unpredictable of death. Parisian Study Group on Acute Pancreatitis. Crit Care Med 1999; 27:749-755.

113. Dambrauskas Z, Giese N, Gulbinas A, et al. Different profiles of cytokine expression during mild and severe acute pancreatitis. World J Gastroenterol 2010; 16:1845-1853. [PubMed: 20397261]

114. Aoun E, Chen J, Reighard D, et al. Diagnostic accuracy of interleukin-6 and interleukin-8 in predicting severe acute pancreatitis: a meta-analysis. Pancreatology 2009; 9:777-785. [PubMed: 20110745]

115. Hirota M, Nozawa F, Okabe A, et al. Relationship between plasma cytokine concentration and multiple organ failure in patients with acute pancreatitis. Pancreas 2000; 21:141-146. [PubMed: 10975707]

116. Amin M, Simerman A, Cho M, et al. 21-hydroxylase-derived steroids in follicles of nonobese women undergoing ovarian stimulation for in vitro fertilization (IVF) positively correlate with lipid content of luteinized granulosa cells (LGCs) as a source of cholesterol for steroid synthesis. J Clin Endocrinol Metab 2014; 99:1299-1306. [PubMed: 24423334]

117. Regner S, Appelros S, Hjalmarsson C, et al. Monocyte chemoattractant protein 1, active carboxypeptidase B and CAPAP at hospital admission are predictive markers for severe acute pancreatitis. Pancreatology 2008; 8:42-49. [PubMed: 18235216]

118. Schaffler A, Hamer OW, Dickopf J. Admission visfatin levels predict pancreatic and peripancreatic necrosis in acute pancreatitis and correlate with clinical severity. Am J Gastroenterol 2011; 106:957-967. [PubMed: 21245835]

119. Miranda CJ, Mason JM, Babu BI, et al. Twenty-four hour infusion of human recombinant activated protein C (Xigris) early in severe acute pancreatitis: the XIG-AP 1 trial. Pancreatology 2015; 15:635-641. [PubMed: 26547592]

120. Pettila V, Kyhala L, Kylanpaa ML, et al. APCAP: activated protein C in acute pancreatitis: a double-blind randomized human pilot trial. Crit Care 2010; 14:R139. [PubMed: 20663207]

121. Hartmann EK, Boehme S, Duenges B, et al. An inhaled tumor necrosis factor-alpha-derived TIP peptide improves the pulmonary function in experimental lung injury. Acta anaesthesiol Scand 2013; 57:334-341. [PubMed: 23216436]

122. Bhargava R, Janssen W, Altmann C, et al. Intratracheal IL-6 protects against lung inflammation in direct, but not indirect, causes of acute lung injury in mice. PloS One 2013; 8:e61405. [PubMed: 23667439] 
123. Wang LZ, Su JY, Lu CY, et al. Effects of recombinant human endothelial-derived interleukin-8 on hemorrhagic shock in rats. Zhongguo Yao Li Xue Bao 1997; 18:434-436. [PubMed: 10322935]

124. Morimoto K, Morimoto A, Nakamori T, et al. Cardiovascular responses induced in free-moving rats by immune cytokines. J Physiol 1992; 448:307-320. [PubMed: 1593469]

125. Wogensen L, Jensen M, Svensson P, et al. Pancreatic beta-cell function and interleukin-1 beta in plasma during the acute phase response in patients with major burn injuries. Eur J Clin Invest 1993; 23:311-319. [PubMed: 8354339]

126. Li S, Ballou LR, Morham SG, Blatteis CM. Cyclooxygenase-2 mediates the febrile response of mice to interleukin-1beta. Brain Res 2001; 910:163-173. [PubMed: 11489266]

127. Maser EA, Deconda D, Lichtiger S, et al. Cyclosporine and infliximab as rescue therapy for each other in patients with steroid-refractory ulcerative colitis. Clin Gastroenterol Hepatol 2008; 6:1112-1116. [PubMed: 18928936]

128. Zeitz J, Huber M, Rogler G. Serious course of a miliary tuberculosis in a 34-year-old patient with ulcerative colitis and HIV infection under concomitant therapy with infliximab. Med Klin (Munich) 2010; 105:314-318. [PubMed: 20455057]

129. Jimenez-Fernandez SG, Tremoulet AH. Infliximab treatment of pancreatitis complicating acute kawasaki disease. Pediatr Infect Dis J 2012; 31:1087-1089. [PubMed: 22653489]

130. Triantafillidis JK, Cheracakis P, Hereti IA, et al. Acute idiopathic pancreatitis complicating active Crohn's disease: favorable response to infliximab treatment. Am J Gastroenterol 2000; 95:3334 3336. [PubMed: 11095387]

131. Fefferman DS, Alsahli M, Lodhavia PJ, et al. Re: Triantafillidis et al.: acute idiopathic pancreatitis complicating active Crohn's disease: favorable response to infliximab treatment. Am J Gastroenterol 2001; 96: 2510-2511. [PubMed: 11513207]

132. Hoque R, Sohail M, Malik A, et al. TLR9 and the NLRP3 inflammasome link acinar cell death with inflammation in acute pancreatitis. Gastroenterology 2011; 141:358-369. [PubMed: 21439959]

133. Kang R, Zhang Q, Hou W, et al. Intracellular Hmgb1 inhibits inflammatory nucleosome release and limits acute pancreatitis in mice. Gastroenterology 2014; 146:1097-1107. [PubMed: 24361123]

134. Yasuda T, Ueda T, Takeyama Y, et al. Significant increase of serum high-mobility group box chromosomal protein 1 levels in patients with severe acute pancreatitis. Pancreas 2006; 33:359363. [PubMed: 17079940]

135. Lindstrom O, Tukiainen E, Kylanpaa L, et al. Circulating levels of a soluble form of receptor for advanced glycation end products and high-mobility group box chromosomal protein 1 in patients with acute pancreatitis. Pancreas 2009; 38:e215-e220. [PubMed: 19786934]

136. Liu T, Huang W, Szatmary P, et al. Accuracy of circulating histones in predicting persistent organ failure and mortality in patients with acute pancreatitis. Br J Surg 2017. This article shows that circulating histones released from dead cells predict persistent organ failure and mortality.

137. Penttila AK, Rouhiainen A, Kylanpaa L, et al. Circulating nucleosomes as predictive markers of severe acute pancreatitis. J Intensive Care 2016; 4:14. [PubMed: 26893906] $\mathbf{D}$ This article shows that circulating nucleosomes released from dead cells predict severe acute pancreatitis.

138. Wu BU, Hwang JQ, Gardner TH, et al. Lactated Ringer's solution reduces systemic inflammation compared with saline in patients with acute pancreatitis. Clin Gastroenterol Hepatol 2011; 9:710.e1-717.e1. [PubMed: 21645639]

139. Aboelsoud MM, Siddique O, Morales A, et al. Fluid choice matters in critically-ill patients with acute pancreatitis: Lactated Ringer's vs. isotonic saline. R I Med J (2013) 2016; 99:39-42. [PubMed: 27706278]

140. Choosakul S, Harinwan K, Chirapongsathorn S, C.P. Comparison of normal saline versus lactated Ringer's solution for resuscitation in patients with acute pancreatitis, a randomized controlled trial. Gastroenterology 2017; 152:S72. The study shows that patients who received Ringer's lactate were less likely to develop SIRS at 24 hours of pancreatitis than patients who received normal saline. 
141. Hoque R, Farooq A, Ghani A, et al. Lactate reduces liver and pancreatic injury in toll-like receptor- and inflammasome-mediated inflammation via GPR81-mediated suppression of innate immunity. Gastroenterology 2014; 146: 1763-1774. [PubMed: 24657625]

142. Yaron RJ, Khatua B, Patel K, et al. The extracellular Ca2+ provided by ringer's lactate but not lactate reduces necrosis and improves survival during severe acute pancreatitis. Gastroenterology 2017; 152:S893. The shows that $\mathrm{Ca}^{2+}$ in Ringer's lactate, but not lactate buffered at $\mathrm{pH} 7.4$ reduced organ failure, and improved survival in mice with severe pancreatitis.

143. Gea-Sorli S, Bonjoch L, Closa D. Differences in the inflammatory response induced by acute pancreatitis in different white adipose tissue sites in the rat. PLoS One 2012; 7:e41933. [PubMed: 22870264]

144. Ahmad FA, Mahmud S. Acute pancreatitis following orlistat therapy: report of two cases. JOP 2010; 11:61-63. [PubMed: 20065556]

145. Kose M, Emet S, Akpinar TS, et al. An unexpected result of obesity treatment: orlistat-related acute pancreatitis. Case Rep Gastroenterol 2015; 9:152-155. [PubMed: 26078734]

146. Napier S, Thomas M. 36 year old man presenting with pancreatitis and a history of recent commencement of orlistat case report. Nutr J 2006; 5:19. [PubMed: 16938137]

147. Badalov N, Baradarian R, Iswara K, et al. Drug-induced acute pancreatitis: an evidence-based review. Clin Gastroenterol Hepatol 2007; 5:648-661. [PubMed: 17395548] 


\section{KEY POINTS}

- Obesity increases acute pancreatitis via gallstones, HTG, drugs, and weight loss interventions.

- $\quad$ Obesity worsens acute pancreatitis via visceral fat lipolysis releasing UFAs that inhibit complexes I and V.

- $\quad$ Lactated Ringer's and parenteral pancreatic lipase inhibitors may decrease acute pancreatitis severity.

- Lactated Ringer's benefit is via calcium, whereas lipase inhibition decreases UFA release. 

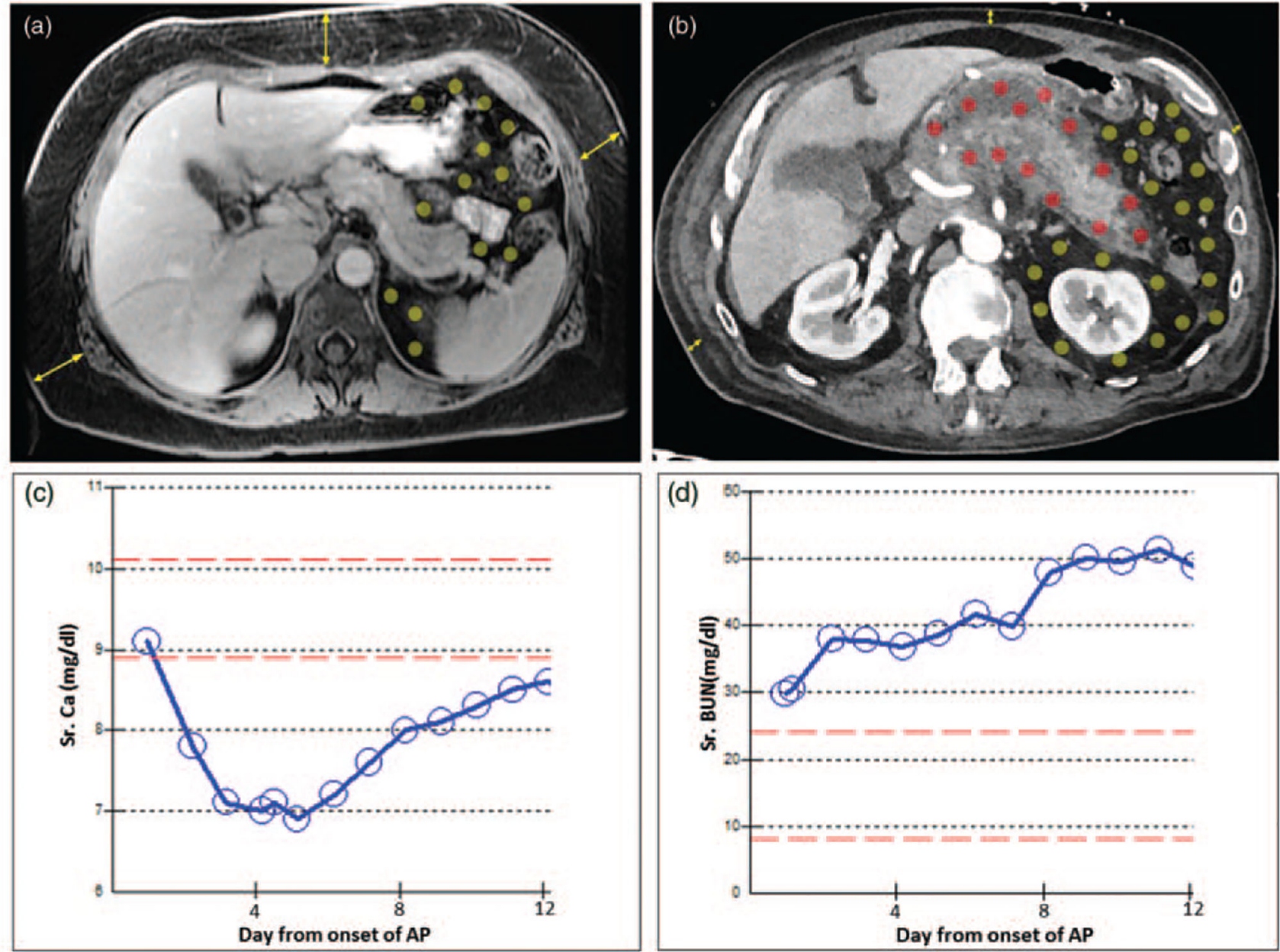

FIGURE 1.

Abdominal imaging showing how location of fat influences the severity of pancreatitis. (a) MRI of a 50-year-old female (weight $85 \mathrm{~kg}$, BMI 34.4) on the second day of biliary pancreatitis showing predominantly subcutaneous fat (yellow arrows) compared with visceral fat (area with yellow dots) with no fat necrosis. The patient had a mild course and was symptom free after 3 days of conservative management. (b) CT scan of a 83-year-old male (weight $84 \mathrm{~kg}$, BMI 26.6) 2 weeks into alcoholic pancreatitis showing little subcutaneous fat (yellow arrows), but a large amount of visceral fat (dots in the peritoneal cavity). The fat around the pancreas was involved in peripancreatic fat necrosis (red dots), whereas the more distant visceral fat remained uninvolved (yellow dots). The clinical course was associated with early hypocalcemia (c), renal failure of $>48 \mathrm{~h}$ (d) and the patient requiring ventilator support. AP, acute pancreatitis; $\mathrm{CT}$, computerized tomography. 


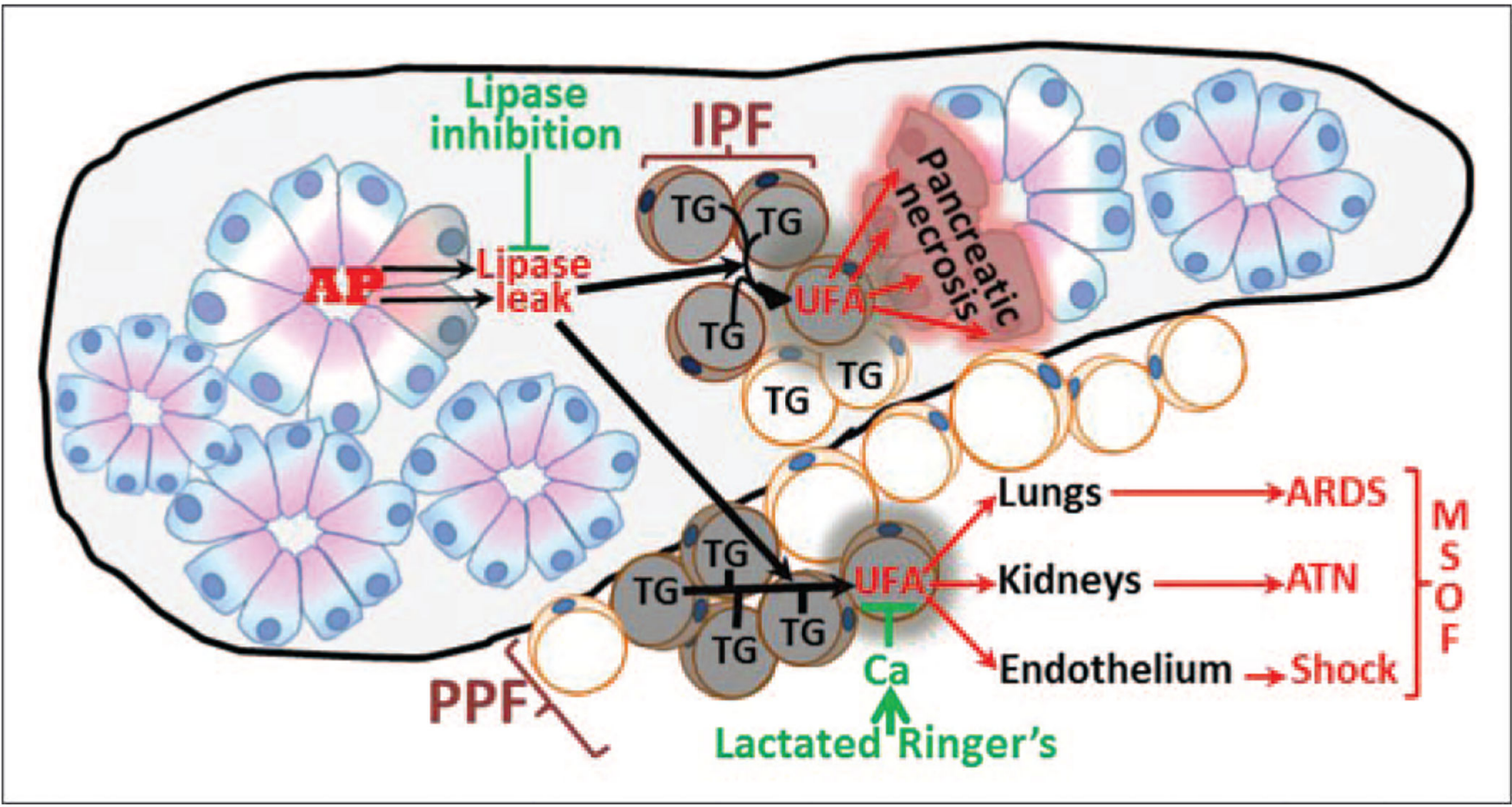

FIGURE 2.

Schematic showing how obesity associated IPF and PPF may, respectively, worsen pancreatic necrosis and lead to MSOF, along with therapeutic interventions (green) that may prevent this exacerbation. AP initiation results in lipase leakage from acinar cells (healthy acini shown in pink and blue, damaged ones orange). This lipase can hydrolyze the TG in IPF and PPF releasing UFAs. When released within the pancreas from IPF, UFAs can worsen pancreatic necrosis, or leak from visceral fat and cause systemic injury resulting in MSOF. AP, acute pancreatitis; IPF, intrapancreatic fat; MSOF, multisystem organ failure; PPF, peripancreatic fat; TG, triglyceride; UFA, unsaturated fatty acid. 
Table 1.

Table summarizing the mechanisms by which obesity may contribute to initiating acute pancreatitis, thus increasing acute pancreatitis incidence, and also worsen acute pancreatitis outcome by increasing local and systemic injury

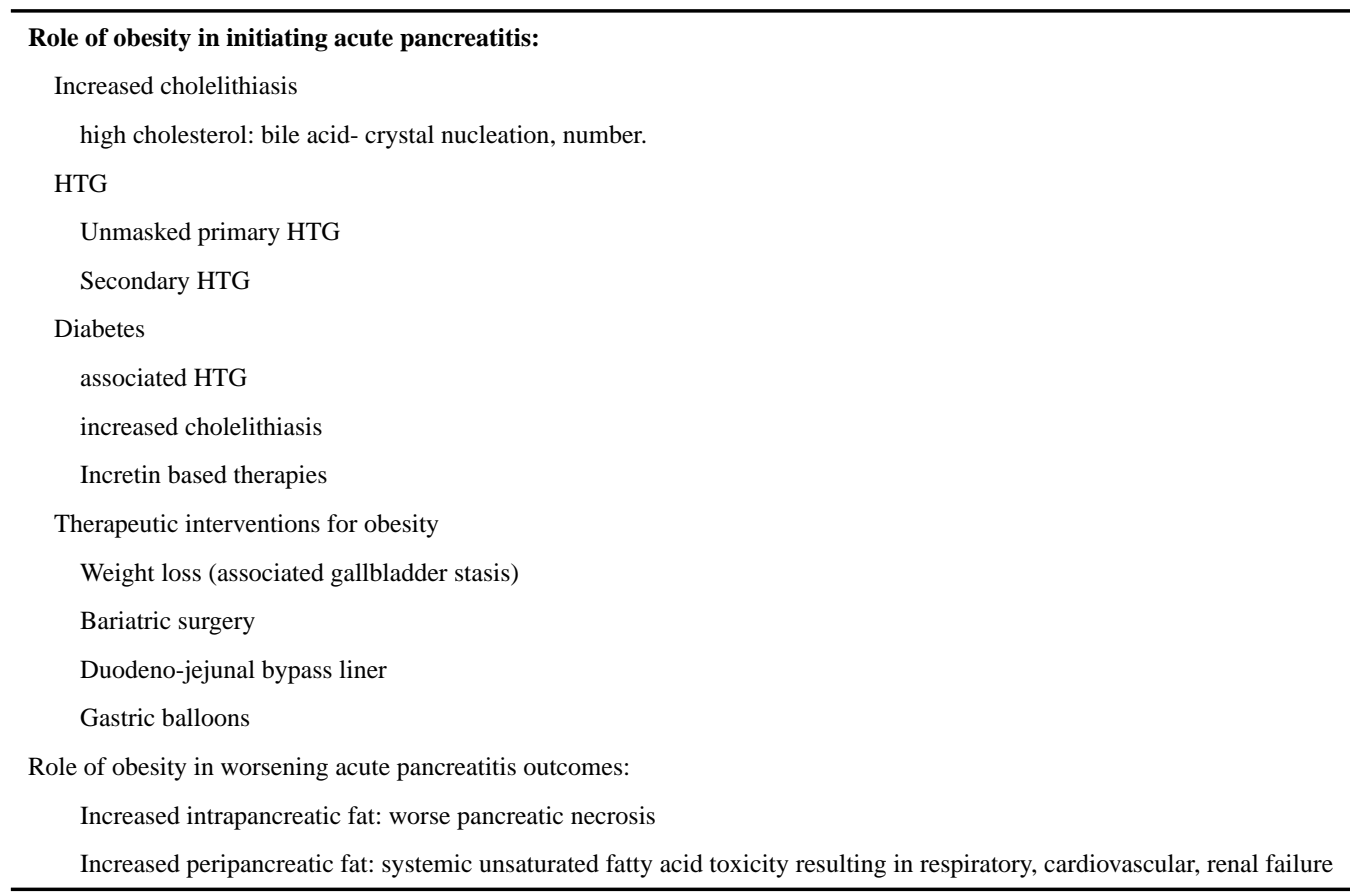

HTG, hypertriglyceridemia. 